\title{
Sources of suspended organic matter and selective feeding by zooplankton in an estuarine mangrove ecosystem as traced by stable isotopes
}

\author{
S. Bouillon ${ }^{1}$, P. Chandra Mohan ${ }^{2}$, N. Sreenivas ${ }^{2}$, F. Dehairs ${ }^{1, *}$ \\ ${ }^{1}$ Department of Analytical Chemistry, Vrije Universiteit Brussel, Pleinlaan 2, 1050 Brussels, Belgium \\ ${ }^{2}$ Department of Zoology, Andhra University, Visakhapatnam 530003, Andhra Pradesh, India
}

\begin{abstract}
Between January 1995 and August 1996, suspended matter and zooplankton were sampled at different locations in a mangrove ecosystem located in the Gautami Godavari estuary and adjacent Kakinada Bay (Andhra Pradesh, India). Suspended matter was sampled at 13 different stations, and was found to have a highly variable carbon stable isotope composition, with $\delta^{13} \mathrm{C}$ values ranging overall between -30.94 and $-19.18 \%$, and a highly variable elemental (C:N) composition. Our data suggest that the phytoplankton component has a seasonally and spatially variable $\delta^{13} \mathrm{C}$ signature, which is surpressed by the terrestrial signal but may at times fall in the same range as the $\delta^{13} \mathrm{C}$ of the allochtonous matter. It is argued that the phytoplankton $\delta^{13} \mathrm{C}$ decreases after the onset of the monsoon rains, most likely due to the ${ }^{13} \mathrm{C}$-depletion of the DIC pool caused by the microbial respiration of the allochtonous organic matter. At each of the 4 sites selected for concurrent zooplankton sampling, the zooplankton showed a much wider range of $\delta^{13} \mathrm{C}$ than did the suspended matter, with overall $\delta^{13} \mathrm{C}$ values between -30.14 and $-16.45 \%$. In addition, spatial differences in average $\delta^{13} \mathrm{C}$ were much more pronounced for zooplankton than for total suspended matter. These data indicate that zooplankton feed on a component of the suspended matter pool, which has more pronounced seasonal and spatial $\delta^{13} \mathrm{C}$ variations than the total suspended matter. Thus, despite the large amounts of terrestrial and mangrove detritus present in the water column, the locally produced phytoplankton appears to be a more important carbon source for the zooplankton.
\end{abstract}

KEY WORDS: Selective feeding $\cdot$ Mangroves $\cdot$ Zooplankton $\cdot$ Suspended organic matter $\cdot$ Phytoplankton $\cdot$ Stable isotopes

\section{INTRODUCTION}

Mangrove forests are often considered to be highly productive tropical ecosystems (Clough 1992). There is, however, still a lot of uncertainty on the fate of the large amounts of leaf litter produced by these systems. The 'outwelling hypothesis', stating that large amounts of mangrove detritus are exported to the aquatic nearshore environment (reviewed by Lee 1995), where they enhance or sustain secondary productivity, has been

*Corresponding author. E-mail: fdehairs@vub.ac.be the subject of much debate. Based on gut-content analysis of mangrove-inhabiting fauna, Odum \& Heald (1975) stated that the major energy flow in these ecosystems occurs via the incorporation of microbially enriched mangrove detritus into secondary producers, which in turn support higher trophic levels. Although an appealing hypothesis, considering the high productivity of these trees compared to other primary producers such as phytoplankton and microphytobenthos (Robertson et al. 1992, Alongi 1994, Gattuso et al. 1998), a number of recent studies have led to the conclusion that the importance of these other primary producers which have a higher nutritional value due to 
their higher nitrogen content, may have been underestimated (Stoner \& Zimmerman 1988, Ambler et al. 1994, Newell et al. 1995, Primavera 1996, Marguillier et al. 1997, Loneragan et al. 1997, France 1998). Similar conclusions have been obtained in a variety of other estuarine systems (e.g. Sullivan \& Moncreiff 1990, Deegan \& Garrit 1997). Others, on the other hand, have concluded that mangrove detrital material constitutes an important food source for many aquatic organisms, yet only on a limited spatial scale, with phytoplankton becoming the primary carbon source in nearby coastal waters (Rodelli et al. 1984).

Suspension-feeding copepods often form the bulk of the zooplankton in estuarine ecosystems. Although results are contradictory, several experiments have shown convincing evidence that, besides being size-selective feeders, these organisms are capable of discriminating between live and dead algae (DeMott 1988, 1995 and references therein). Most of these results were obtained in laboratory experiments where copepods were offered only pairs of different particles, and DeMott (1995) stresses that these may be misleading or irrelevant to understanding copepod feeding selectivity under natural conditions. Estuarine zooplankton, however, are often considered to be indiscriminate, nonselective feeders (e.g. Hummel et al. 1988, Turner \& Tester 1989). Considering the potentially important role of zooplankton as a trophic link between primary producers and higher trophic levels, which include many commercially important species, it is surprising that most stable isotope studies in mangrove ecosystems have not incorporated zooplankton analysis (Rodelli et al. 1984, Fleming et al. 1990, Newell et al. 1995) or have been limited to a relatively small number of measurements (Stoner \& Zimmerman 1988, Ambler et al. 1994, Dittel et al. 1997, Marguillier et al. 1997) and did not include a thorough discussion of the possible carbon sources for zooplankton. As Robertson et al. (1992) noted, the relative importance of mangrove carbon and other sources to zooplankton nutrition in these ecosystems thus remains largely unknown.

Analysis of the natural abundance of carbon and nitrogen stable isotopes provides a powerful method to trace sources and transfer of organic matter through foodwebs (Peterson \& Fry 1987), provided that different primary producers have a distinct isotopic signature, and based on the assumptions that fractionation of ${ }^{13} \mathrm{C}$ between an organism and its diet is small or negligible (0 to $1 \%$; DeNiro \& Epstein 1978), and that organisms are enriched in ${ }^{15} \mathrm{~N}$ relative to their diet by an average of 2.6 (Owens 1987) to $3.4 \%$ (Minagawa $\&$ Wada 1984). These fractionation values should be treated with some caution, as there is some recent evidence for differences in ${ }^{15} \mathrm{~N}$ enrichment depending on the nitrogen content of an organism's diet (Fantle et al.
1999). Elemental and stable isotope analysis has been used in a large number of studies to determine the spatial and/or temporal distribution of different sources of organic matter (allochthonous detritus and local phytoplankton) in suspended matter and sediments of estuarine systems (e.g. Cifuentes et al. 1996, Ogawa \& Ogura 1997, Middelburg \& Nieuwenhuize 1998, Hellings et al. 1999). The majority of these studies focus on temperate ecosystems, but several authors have used this approach to characterise suspended organic matter sources in tropical mangrove ecosystems (Rezende et al. 1990, Hemminga et al. 1994, Cifuentes et al. 1996, Dehairs et al. 2000). These studies have shown that suspended organic matter in these systems is comprised of a highly variable proportion of terrestrial detritus and algae (and seagrasses when present), and that substantial spatial, seasonal, and tidal variations in the $\delta^{13} \mathrm{C}$ signal of suspended matter may occur. Such variations should be taken into account when suspended matter $\delta^{13} \mathrm{C}$ data are used in foodweb analysis (Goering et al. 1990, Cifuentes et al. 1996), but this aspect is still neglected in many studies. Large seasonal and spatial variations have also been observed in zooplankton $\delta^{13} \mathrm{C}$ and $\delta^{15} \mathrm{~N}$, both in marine and coastal environments (Fry \& Wainright 1991, Malej et al. 1993, Wainright \& Fry 1994, Zohary et al. 1994 and references therein) and freshwater ecosystems (Toda \& Wada 1990, Yoshioka et al. 1990), with variability generally being larger in freshwater ecosystems (Zohary et al. 1994).

In this study, we wanted to gain insight into the sources of organic matter present in the suspended material in an estuarine mangrove ecosystem located near the mouth of the Gautami Godavari, Andhra Pradesh, India, by measuring elemental (C:N) and stable carbon-isotope ratios in suspended particulate organic matter (SPOM), collected at monthly intervals between January 1995 and August 1996 at 13 different locations, representing different environmental conditions. In addition, we wanted to assess whether the use of stable carbon- and nitrogen-isotope ratios could provide evidence for selective or non-selective feeding of zooplankton on different components of suspended matter. These data would also provide some baseline information on the spatio-temporal variability of suspended matter and zooplankton isotope ratios, which could be useful for further studies on the trophic dynamics in this ecosystem.

\section{MATERIALS AND METHODS}

Study area. The study site (Fig. 1) comprises the area between Kakinada Bay and the Gautami Godavari branch of the Godavari, the second largest 


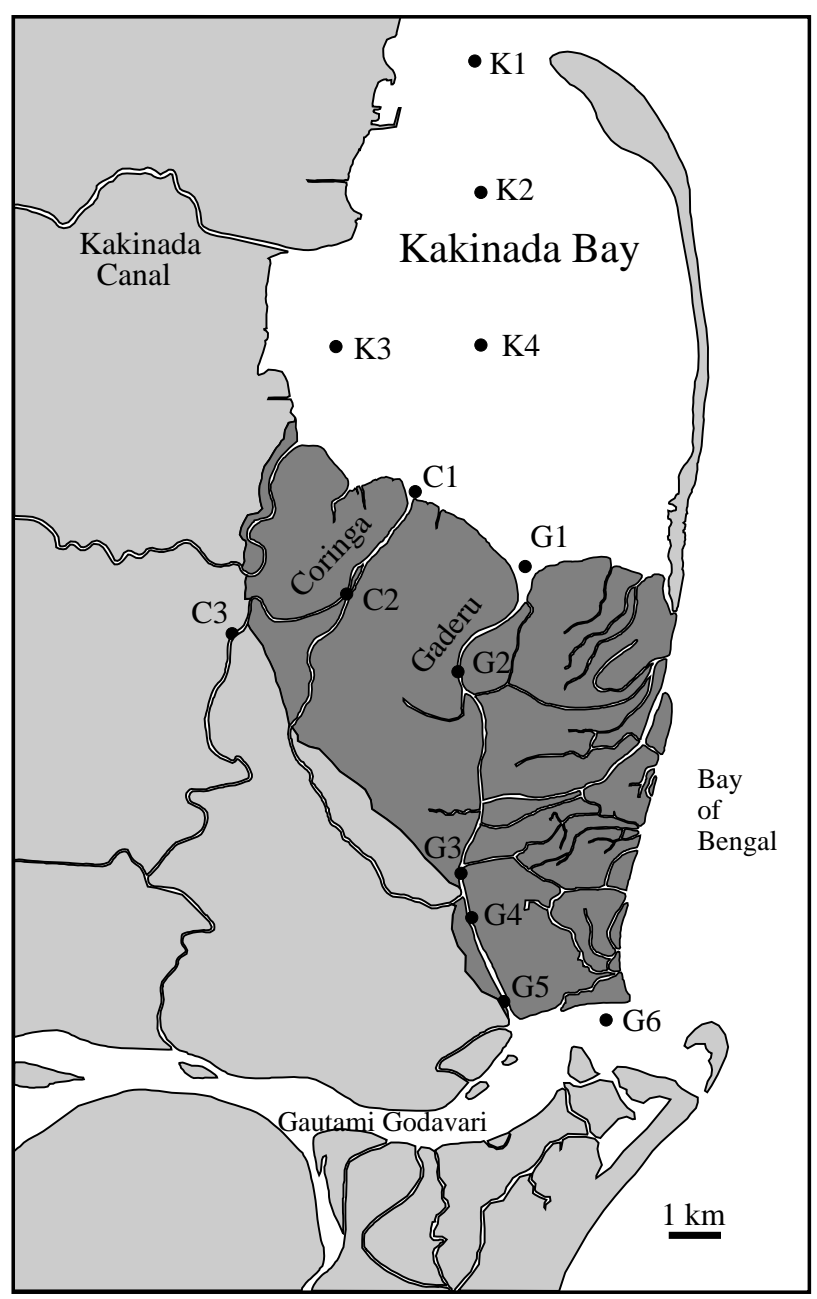

Fig. 1. Map of study area, showing major waterways and sampling locations $(\bullet)$. Dark areas represent main mangrovecovered areas

river in India, and is located in the southeastern state of Andhra Pradesh (between $16^{\circ} 43^{\prime}$ and $17^{\circ} 00^{\prime} \mathrm{N}$, and $82^{\circ} 15^{\prime}$ and $\left.82^{\circ} 22^{\prime} \mathrm{E}\right)$. The Godavari has a mean annual discharge of $1.1 \times 10^{11} \mathrm{~m}^{3}$, of which 93 to $96 \%$ occurs during the wet monsoon, and it is recognized as one of the largest POC (particulate organic carbon)-transporting rivers in the world (Gupta et al. 1997). The Gautami Godavari opens into the Bay of Bengal, but has several branches into Kakinada Bay, the largest and most important being Coringa (total length of $26 \mathrm{~km}$ ) and Gaderu (total length of $11 \mathrm{~km}$ ). The area is dominated by mangrove forests and tidal mudflats, the most abundant species being Avicennia marina, A. officinalis, Excoecaria agallocha, Sonneratia apetala, Rhizophora mucronata and $R$. apiculata (Azariah et al. 1992, Satyanarayana 1997). The shallow Kakinada Bay (depth at high tide ranging from 3 to $8 \mathrm{~m}$ ), which covers approximately $150 \mathrm{~km}^{2}$, opens into the sea on its northern side, and is bordered along most of its eastern length by a narrow sand bar, which experienced a breakthrough along its southern end after the November 1996 cyclone. Tides are semidiurnal, and tidal amplitude in the Bay varies between 2.3 and $4.5 \mathrm{~m}$ (Sreenivas 1998), but is less in the mangrove-covered areas.

The town of Kakinada (population 500 000), which hosts a large fishing harbour and several fertiliser factories, is located on the west side of Kakinada Bay. The whole area serves as an important fishing area for the local community, as well as for the collection of crabs, prawn 'seed' (mainly Penaeus monodon and P. indicus), and firewood. Due to increased human pressure (sewage, aquaculture ponds) and pollution, the area has witnessed a significant decline in biodiversity during the last 40 yr (Chandra Mohan et al. 1997).

In general, 4 seasons can be distinguished in the area, although substantial year-to-year variations in this pattern can be observed: (1) a cool and dry season from December to February; (2) a hot and relatively dry period from March to June; (3) abundant rains during the hot Southwest monsoon (July to September), when almost freshwater conditions prevail in the whole area; (4) a cooler transitional period during which estuarine and marine conditions are re-established in the Bay and mangrove creeks (October to November).

During the period of this study, however, a bimodal rainfall distribution was noticed, with highest rainfall occurring in May 1996 and November 1996.

Sample collection and preparation. During the period from January 1995 to August 1996, zooplankton samples were collected at 4 different locations, representing different environmental and hydrological settings (Fig. 1): Kakinada North Bay $\left(\mathrm{K}_{2}\right)$, at the mouth of Coringa $\left(\mathrm{C}_{1}\right)$, central Gaderu $\left(\mathrm{G}_{3}\right)$, and at the mouth of the Gautami Godavari $\left(\mathrm{G}_{6}\right)$. Suspended matter was collected at approximately monthly intervals at these and 9 additional locations. As it was impossible to collect all samples at the same tidal elevation, we examined the tidal variability of $\delta^{13} \mathrm{C}_{\mathrm{SPOM}}$ at 1 station $\left(\mathrm{G}_{3}\right)$ during a $24 \mathrm{~h}$ period in November 1995.

Zooplankton samples were collected by towing a $120 \mu \mathrm{m}$ plankton net equipped with a calibrated TSK flow meter at its opening. Material for stable isotope analysis was kept in a cool box on board, and transported to the field laboratory, where it was washed and dried at $60^{\circ} \mathrm{C}$ for $24 \mathrm{~h}$. Subsamples were fixed on board in $5 \%$ formaldehyde for quantitative studies and identification as discussed in Chandra Mohan et al. (1997) and Sreenivas (1998). Samples were ground to a fine powder, and subsamples for $\delta^{13} \mathrm{C}$ analysis were washed with diluted $\mathrm{HCl}$ to remove carbonates, and redried. Subsamples for $\delta^{15} \mathrm{~N}$ analysis did not receive this acid treatment, as this has been reported 
to affect $\delta^{15} \mathrm{~N}$ values (Goering et al. 1990, Bunn et al. 1995). SPOM samples were obtained by collecting approx. $250 \mathrm{ml}$ of subsurface water, which was kept in a cool box during transport, and was later filtered on pre-combusted glass-fibre filters (Whatman GF/F). Filters were then dried at $60^{\circ} \mathrm{C}$ for $24 \mathrm{~h}$ and decalcified under acid vapour. Due to their low nitrogen content, no SPOM $\delta^{15} \mathrm{~N}$ measurements could be made. Salinity data are to be found in Murthy (1997) and Sreenivas (1998).

Measurement of elemental and stable isotope ratios. Most data on elemental $(\mathrm{C}: \mathrm{N})$ ratios of SPOM were taken from Dehairs et al. (2000). Some additional measurements were made using a Carlo Erba NA1500 Elemental Analyser. Samples for stable isotope analysis were combusted in the same instrument, and the resulting gases $\left(\mathrm{CO}_{2}\right.$ and $\left.\mathrm{N}_{2}\right)$ were separated by cryopurification using a Finnigan Mat CT-NT Trapping box (for $\mathrm{CO}_{2}$ ), or with a manual extraction line (for $\mathrm{CO}_{2}$ and $\mathrm{N}_{2}$ ). Stable isotope ratios were then measured on a Delta E Finnigan Mat isotope-ratio mass spectrometer, and are expressed relative to the conventional standards, i.e. PDB limestone for carbon (Coplen 1996) and atmospheric $\mathrm{N}_{2}$ for nitrogen, as $\delta$ values, defined as:

$$
\delta R=\left[\left(X_{\text {sample }}-X_{\text {standard }}\right) / X_{\text {standard }}\right] \times 10^{3}(\%)
$$

where $R={ }^{13} \mathrm{C}$ or ${ }^{15} \mathrm{~N}$, and $X={ }^{13} \mathrm{C} /{ }^{12} \mathrm{C}$ or ${ }^{15} \mathrm{~N} /{ }^{14} \mathrm{~N}$. The normal working standard for carbon was $\mathrm{CO}_{2}$ produced from carrara marble, and atmospheric $\mathrm{N}_{2}$ was used as the working standard for nitrogen. The standard deviation of 10 aliquots of the same sample was lower than 0.17 and $0.2 \%$ for $\delta^{13} \mathrm{C}$ and $\delta^{15} \mathrm{~N}$, respectively.

\section{RESULTS}

\section{Elemental and stable carbon-isotope composition of suspended matter}

SPOM $\delta^{13} \mathrm{C}$ values varied overall between -30.94 and $-19.18 \%$, but average values per location ranged from a minimum of -25.51 (at $\mathrm{C}_{1}$ and $\mathrm{C}_{2}$ ) to $-22.73 \%$ (at $\mathrm{K}_{3}$ ) (Table 1).

Suspended matter was, on average, more enriched in ${ }^{13} \mathrm{C}$ at the bay stations, although significant overlap occurred (Fig. 2, Table 1). Contrary to the expectation that this enrichment would increase along a linear gradient towards the bay opening, i.e. from $\operatorname{Stn} \mathrm{K}_{4}$ via $\mathrm{K}_{2}$ to $\mathrm{K}_{1}$, the reverse pattern was observed (average $\delta^{13} \mathrm{C}$ values $=K_{1}:-23.55 \% ; K_{2}:-23.33 \%$; $K_{4}:-22.83 \%$ ), and most ${ }^{13} \mathrm{C}$-enriched values $(-22.73 \%$ ) were observed at $\mathrm{K}_{3}$. Using a paired $t$-test, this enrichment of $\mathrm{K}_{4}$ relative to $K_{1}$ was significant ( $p=0.041 ; \alpha=0.05$ ), although the average difference was relatively small $(0.72 \%$ o). A paired $t$-test revealed that $K_{2}, K_{3}$, and $K_{4}$ differed significantly from all Coringa, Gaderu and Gautami Godavari stations ( $p<0.043 ; \alpha=0.05)$, but SPOM from the northernmost station $\left(\mathrm{K}_{1}\right)$ was found to differ only from the 3 Coringa stations and the Gaderu stations $G_{2}$ $(p=0.018 ; \alpha=0.05), G_{3}(p=0.004 ; \alpha=0.05)$ and $G_{4}$ ( $p=0.006 ; \alpha=0.05)$. Most depleted average $\delta^{13} \mathrm{C}_{\mathrm{SPOM}}$ values were observed in the 3 Coringa stations, which all had an average value of $-25.5 \%$ (Table 1, Fig. 2). In Gaderu, suspended matter was found to be most depleted in ${ }^{13} \mathrm{C}$ in the central station $\left(\mathrm{G}_{3}:-25.21 \%\right.$ ), and became more enriched both towards Kakinada Bay $\left(\mathrm{G}_{2}:-24.86 \% ; \mathrm{G}_{1}:-23.98 \%\right.$ ) and towards the Gautami Godavari opening $\left(\mathrm{G}_{4}:-25.12 \% \mathrm{G}_{5}:-24.32 \%\right.$ ) (Table 1,

Table 1. Average $( \pm 1 \mathrm{SD})$, minimum and maximum stable carbon-isotope ratios $\left(\delta^{13} \mathrm{C}, \%\right)$ and elemental $(\mathrm{C}: \mathrm{N})$ ratios of suspended particulate organic matter (SPOM), and average salinity (\%o) at different sampling locations in the Gautami Godavari estuarine region. Abbreviations of sampling locations as in Fig. 1. Numbers in parentheses: number of samples analysed. Most C:N ratios from Dehairs et al. (2000), salinity data from Murthy (1997)

\begin{tabular}{|c|c|c|c|c|c|c|c|}
\hline Stn & $\delta^{13} \mathrm{C} \pm 1 \mathrm{SD}$ & Min. $\delta^{13} \mathrm{C}$ & Max. $\delta^{13} \mathrm{C}$ & $\mathrm{C}: \mathrm{N} \pm 1 \mathrm{SD}$ & Min. C:N & Max. C:N & Salinity \\
\hline $\mathrm{K}_{1}$ & $-23.55 \pm 1.25(\mathrm{n}=16)$ & -25.97 & -20.82 & $9.98 \pm 4.88(\mathrm{n}=15)$ & 5.4 & 23.6 & 28.5 \\
\hline $\mathrm{K}_{2}$ & $-23.33 \pm 1.25(\mathrm{n}=17)$ & -25.75 & -21.71 & $8.52 \pm 2.44(\mathrm{n}=17)$ & 5.8 & 14.0 & 27.3 \\
\hline $\mathrm{K}_{3}$ & $-22.73 \pm 2.15(\mathrm{n}=16)$ & -26.30 & -19.18 & $8.26 \pm 2.44(\mathrm{n}=15)$ & 5.0 & 13.5 & 23.5 \\
\hline $\mathrm{K}_{4}$ & $-22.83 \pm 1.52(\mathrm{n}=17)$ & -26.43 & -20.68 & $8.49 \pm 3.21(n=15)$ & 4.8 & 17.3 & 25.8 \\
\hline $\mathrm{C}_{1}$ & $-25.51 \pm 1.53(\mathrm{n}=13)$ & -28.81 & -23.66 & $11.94 \pm 8.79(n=13)$ & 5.6 & 32.7 & 10.6 \\
\hline $\mathrm{C}_{2}$ & $-25.51 \pm 0.86(n=13)$ & -26.59 & -23.71 & $12.74 \pm 11.18(\mathrm{n}=12)$ & 5.1 & 38.0 & 6.5 \\
\hline $\mathrm{C}_{3}$ & $-25.50 \pm 1.13(n=13)$ & -26.83 & -23.39 & $13.41 \pm 12.18(\mathrm{n}=11)$ & 6.2 & 42.4 & 4.2 \\
\hline $\mathrm{G}_{1}$ & $-23.98 \pm 1.23(\mathrm{n}=16)$ & -26.41 & -22.00 & $9.29 \pm 3.45(\mathrm{n}=15)$ & 6.0 & 20.5 & 18.8 \\
\hline $\mathrm{G}_{2}$ & $-24.86 \pm 1.85(n=16)$ & -30.94 & -23.15 & $8.71 \pm 2.86(n=15)$ & 5.0 & 15.2 & 17.5 \\
\hline $\mathrm{G}_{3}$ & $-25.21 \pm 1.58(\mathrm{n}=18)$ & -29.48 & -23.22 & $8.29 \pm 2.46(n=15)$ & 5.7 & 13.2 & 17.6 \\
\hline $\mathrm{G}_{4}$ & $-25.12 \pm 1.64(\mathrm{n}=16)$ & -29.05 & -23.22 & $8.67 \pm 3.89(\mathrm{n}=15)$ & 6.3 & 20.5 & 15.3 \\
\hline $\mathrm{G}_{5}$ & $-24.32 \pm 1.65(n=16)$ & -27.05 & -20.95 & $10.08 \pm 5.61(\mathrm{n}=15)$ & 3.9 & 27.8 & 16.3 \\
\hline $\mathrm{G}_{6}$ & $-24.65 \pm 1.31(\mathrm{n}=17)$ & -27.52 & -22.31 & $9.23 \pm 3.42(\mathrm{n}=15)$ & 5.4 & 17.2 & 15.6 \\
\hline
\end{tabular}




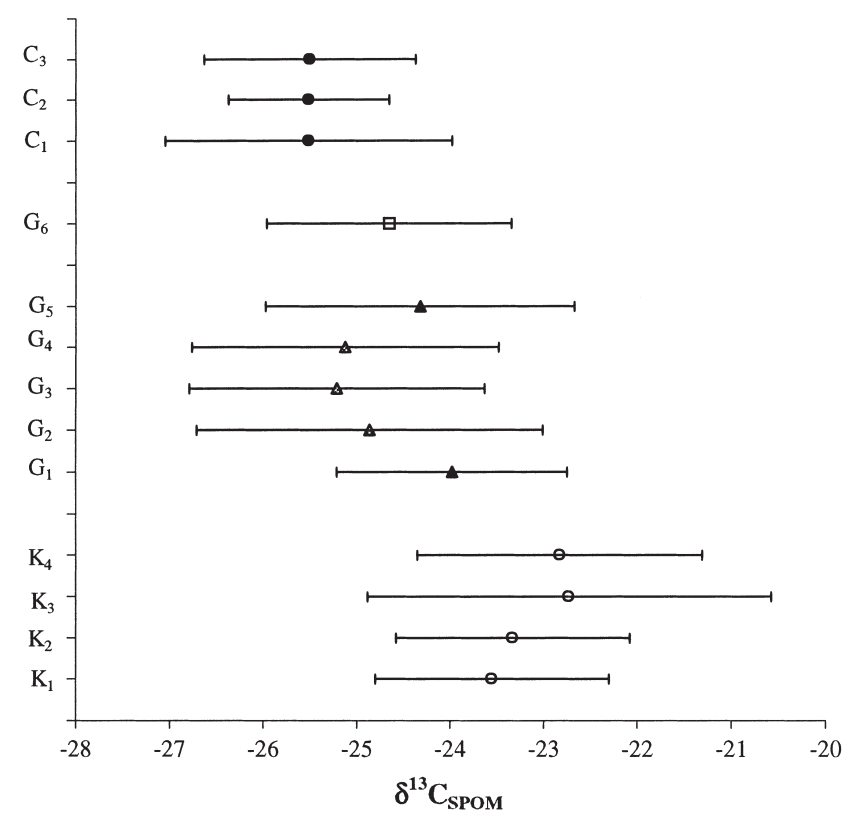

Fig. 2. Average stable carbon-isotope ratios (\%o) of suspended particulate organic matter (SPOM), collected at different locations in the Gautami Godavari estuarine region between January 1995 and July 1996. Error bars $= \pm 1$ SD. Sampling locations (ordinate) are shown in Fig. 1

Fig. 2). This enrichment compared to $G_{3}$ is significant (paired $t$-test) in $\mathrm{G}_{1}(\mathrm{p}=0.0077 ; \alpha=0.05)$ and $\mathrm{G}_{5}(\mathrm{p}=$ $0.012 ; \alpha=0.05)$. At the Gautami Godavari station $\left(\mathrm{G}_{6}\right)$, suspended matter had an average $\delta^{13} \mathrm{C}$ of $-24.65 \%$.
Seasonal variations in SPOM $\delta^{13} \mathrm{C}$ values (i.e. the range of $\delta^{13} \mathrm{C}$ values observed) at each location were larger than the average differences in SPOM $\delta^{13} \mathrm{C}$ between different locations. An apparent depletion in ${ }^{13} \mathrm{C}$ can be observed during the transitional and dry season (between October and February), and is most pronounced in the Coringa and Gaderu stations (Fig. 3, Table 2).

Overall, C:N ratios of suspended matter ranged from 3.9 to 42.4 ; but average values for all stations were between 8.3 (at $\mathrm{G}_{3}$ and $\mathrm{K}_{3}$ ) and 13.4 (at $\mathrm{C}_{3}$ ) (Table 1, Fig. 4). Suspended matter samples with $\mathrm{C}: \mathrm{N}$ ratios higher than 12 are often considered to be indicative of containing mainly terrestrial detritus (Faganeli et al. 1988, Cifuentes et al. 1996). As shown in Fig. 4 (dotted line), these have an average $\delta^{13} \mathrm{C}$ value of $-25.93 \%$, which is within the range of values reported for typical terrestrial C3-plants (Peterson \& Fry 1987). The bulk of samples with lower C:N ratios (including all but 4 of the Kakinada Bay and Gautami Godavari samples) are enriched in ${ }^{13} \mathrm{C}$ relative to this detrital signal, but about $23 \%$ of all samples, the majority of which come from Coringa and Gaderu, are depleted in ${ }^{13} \mathrm{C}$ (Fig. 4).

During the tidal cycle recorded at Gaderu Stn $\mathrm{G}_{3}$ in November $1995, \delta^{13} \mathrm{C}_{\mathrm{SPOM}}$ varied between -26.51 and $-28.30 \%$, and was well correlated with salinity fluctuations $\left(\mathrm{R}^{2}=0.62 ; \mathrm{p}=0.012\right)$, with low $\delta^{13} \mathrm{C}_{\mathrm{SPOM}}$ values occurring at lower salinity (low-tide period) (Fig. 5).

Table 2. Seasonal variations in suspended matter $\delta^{13} \mathrm{C}(\%)$ at the different sampling locations. ${ }^{*}$ Data from Dehairs et al. (2000). Abbreviations of sampling locations as in Fig. 1. nd: not determined

\begin{tabular}{|c|c|c|c|c|c|c|c|c|c|c|c|c|c|}
\hline \multirow[t]{2}{*}{ Month } & \multicolumn{4}{|c|}{ Kakinada Bay } & \multicolumn{3}{|c|}{ Coringa } & \multicolumn{5}{|c|}{ Gaderu } & \multirow{2}{*}{$\begin{array}{c}\text { Gautami } \\
\text { Godavari } \\
\mathrm{G}_{6}\end{array}$} \\
\hline & $\mathrm{K}_{1}$ & $\mathrm{~K}_{2}$ & $\mathrm{~K}_{3}$ & $\mathrm{~K}_{4}$ & $\mathrm{C}_{1}$ & $\mathrm{C}_{2}$ & $\mathrm{C}_{3}$ & $\mathrm{G}_{1}$ & $\mathrm{G}_{2}$ & $\mathrm{G}_{3}$ & $\mathrm{G}_{4}$ & $\mathrm{G}_{5}$ & \\
\hline Jan 95 & -23.04 & -22.46 & -23.01 & -22.04 & nd & nd & nd & -25.36 & -30.94 & -26.94 & -28.02 & -26.70 & -25.18 \\
\hline Feb 95 & -23.67 & -22.91 & -22.49 & -21.98 & nd & nd & nd & -23.37 & -25.21 & -24.32 & -23.82 & -22.65 & -22.76 \\
\hline Mar 95 & nd & $-22.95^{*}$ & $-21.99^{*}$ & $-22.55^{*}$ & nd & nd & nd & $-23.64^{*}$ & $-24.07^{*}$ & $-24.21^{*}$ & $-23.64^{*}$ & $-23.17^{*}$ & $-23.36^{*}$ \\
\hline Apr 95 & -20.82 & -22.38 & -20.00 & -20.68 & -26.34 & -25.58 & -23.39 & -22.18 & -23.87 & -24.11 & -24.75 & -24.00 & -24.02 \\
\hline May 95 & -23.35 & -21.71 & -19.78 & -21.29 & -24.17 & -24.24 & -25.51 & -23.60 & -24.68 & -24.12 & -25.01 & -24.40 & -25.18 \\
\hline Jun 95 & $-23.67^{*}$ & $-22.32^{*}$ & -22.37 & $-22.85^{*}$ & $-23.66^{*}$ & $-25.61^{*}$ & $-26.39^{*}$ & $-22.88^{*}$ & $-24.49^{*}$ & $-25.03^{*}$ & $-24.41^{*}$ & $-24.30^{*}$ & $-22.81^{*}$ \\
\hline Jul 95 & -24.12 & -24.90 & -23.76 & -23.91 & -26.41 & -25.84 & -25.04 & -24.38 & -23.59 & -23.46 & -23.58 & -23.01 & nd \\
\hline Aug 95 & $-23.71^{*}$ & $-22.43^{*}$ & $-21.90^{*}$ & $-21.79^{*}$ & $-24.10^{*}$ & $-25.46^{*}$ & $-24.60^{*}$ & $-24.12^{*}$ & $-23.15^{*}$ & $-23.22^{*}$ & $-24.59^{*}$ & $-24.95^{*}$ & $-22.31^{*}$ \\
\hline Sep 95 & -23.05 & -22.56 & -24.58 & -23.43 & -26.07 & -25.99 & -25.87 & -25.65 & -24.53 & -26.14 & -25.02 & -24.29 & -25.39 \\
\hline Oct 95 & -23.78 & -25.11 & -26.30 & -26.43 & -26.49 & -26.41 & -26.67 & -24.52 & -24.38 & -26.77 & -25.42 & -24.37 & -25.84 \\
\hline Nov 95 & -22.42 & -22.76 & -26.27 & -22.01 & -28.81 & -26.59 & -26.83 & -23.49 & -24.54 & -29.48 & -29.05 & -27.05 & -27.52 \\
\hline Dec 95 & $-25.10^{*}$ & $-24.09^{*}$ & $-22.16^{*}$ & $-24.08^{*}$ & $-24.26^{*}$ & $-25.04^{*}$ & $-23.95^{*}$ & $-24.69^{*}$ & $-25.01^{*}$ & $-24.96^{*}$ & $-24.51^{*}$ & $-24.18^{*}$ & $-24.16^{*}$ \\
\hline Jan 96 & -24.25 & -24.93 & -24.83 & -24.39 & -27.24 & -26.44 & -26.67 & -26.41 & -26.78 & -26.64 & -27.12 & -26.08 & -25.08 \\
\hline Feb 96 & -25.97 & -25.75 & -24.09 & -23.67 & -25.25 & -25.80 & -26.50 & -24.69 & -25.47 & -26.15 & -25.64 & -26.37 & -25.69 \\
\hline Mar 96 & nd & nd & nd & nd & nd & nd & nd & nd & nd & nd & nd & nd & nd \\
\hline Apr 96 & -21.78 & -21.77 & -19.18 & -21.57 & -24.01 & -23.71 & -24.46 & -22.74 & -23.40 & -24.22 & -24.16 & -20.95 & -25.09 \\
\hline May 96 & -23.20 & -23.69 & -21.00 & -21.00 & -24.89 & -24.85 & -25.63 & -22.00 & -23.63 & -23.52 & -23.22 & -22.73 & -25.11 \\
\hline Jun 96 & -24.82 & $-23.96^{*}$ & nd & -24.44 & nd & nd & nd & nd & nd & $-25.25^{*}$ & nd & nd & $-24.53^{*}$ \\
\hline Jul 96 & nd & nd & nd & nd & nd & nd & nd & nd & nd & $-25.26^{*}$ & nd & nd & $-25.01^{*}$ \\
\hline
\end{tabular}



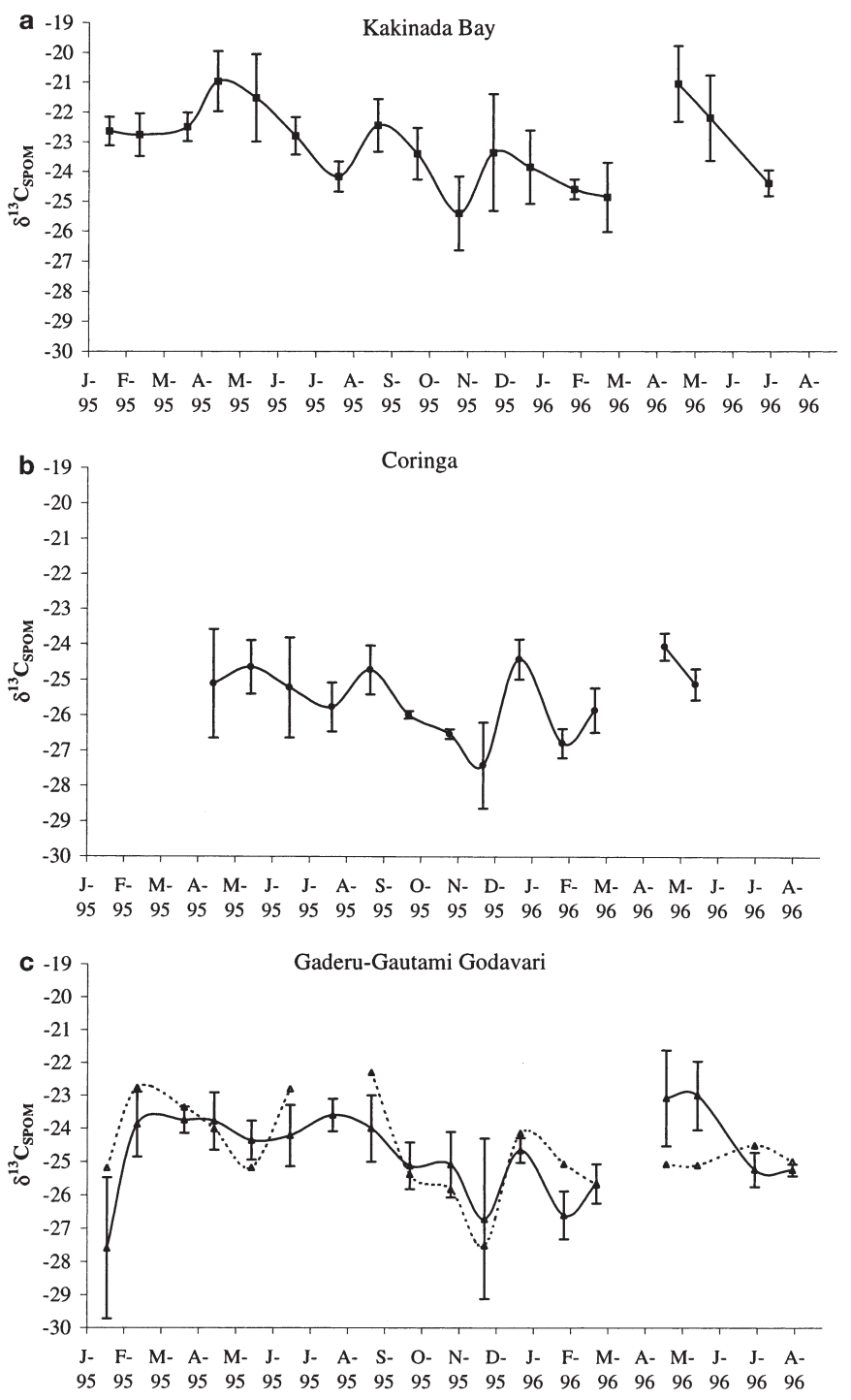

Fig. 3. Average suspended matter $\delta^{13} \mathrm{C}(\%)$, from the different sampling stations in (a) Kakinada Bay, (b) Coringa, and (c) Gaderu (continuous line) and Gautami Godavari (dotted line) from January 1995 to August 1996. Error bars $= \pm 1 \mathrm{SD}$

\section{Stable carbon- and nitrogen-isotope composition of zooplankton}

The overall range of $\delta^{13} \mathrm{C}$ values for zooplankton $(-30.13$ to $-16.45 \%$ ) was larger than the range of $\delta^{13} \mathrm{C}_{\mathrm{SPOM}}$ values from the same locations $(-29.48$ to $-21.71 \%$; Tables 1 \& 3). Zooplankton were most enriched in ${ }^{13} \mathrm{C}$ in Kakinada Bay $\left(\mathrm{Stn} \mathrm{K}_{2}\right.$, average $\delta^{13} \mathrm{C}_{\mathrm{ZP}}=$ $-21.02 \%$ ), but exhibited the largest range at this station $(-28.19$ to $-16.45 \%)$. The average zooplankton $\delta^{13} \mathrm{C}$ at the 4 sampling locations followed the same trend in ${ }^{13} \mathrm{C}$-depletion as the suspended matter from these stations (i.e. $\mathrm{K}_{2}>\mathrm{G}_{6}>\mathrm{G}_{3}>\mathrm{C}_{1}$ ), but the $\delta^{13} \mathrm{C}$ gradient was more pronounced in the zooplankton, caus-
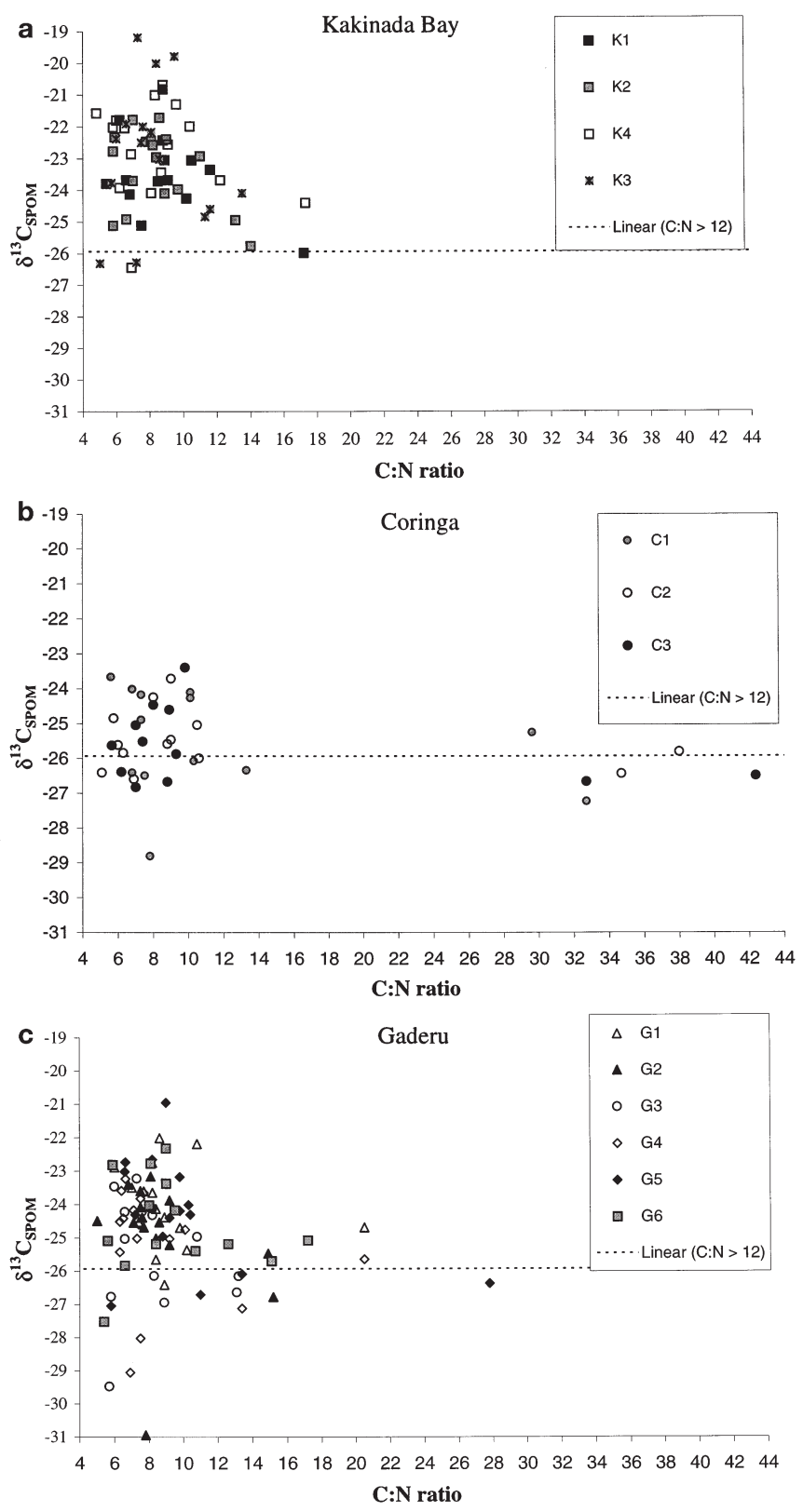

Fig. 4. Elemental (C:N) vs stable carbon-isotope composition $\left(\delta^{13} \mathrm{C}, \%\right)$ of suspended particulate organic matter (SPOM) from the different sampling stations in (a) Kakinada Bay, (b) Coringa, and (c) Gaderu $\left(\mathrm{G}_{1}-\mathrm{G}_{5}\right)$ and Gautami Godavari $\left(\mathrm{G}_{6}\right)$. Horizontal dotted lines represent average $\delta^{13} \mathrm{C}_{\mathrm{SPOM}}$ $(-25.93 \%)$ for all samples with C:N > 12

ing zooplankton to be on average enriched in ${ }^{13} \mathrm{C}$ relative to the suspended matter at $\mathrm{K}_{2}$ (by $1.80 \%$ when using only data from months when both parameters were measured), $\mathrm{G}_{6}$ (by $2.92 \%$ ) and in $\mathrm{G}_{3}$ (by $0.07 \%$ ), but depleted at $\mathrm{C}_{1}$ (by $0.10 \%$ ) (Fig. 6). It should be noted, however, that there was a large variation in the $\delta^{13} \mathrm{C}$ difference of concurrently collected zooplankton and suspended matter (Fig. 7). 


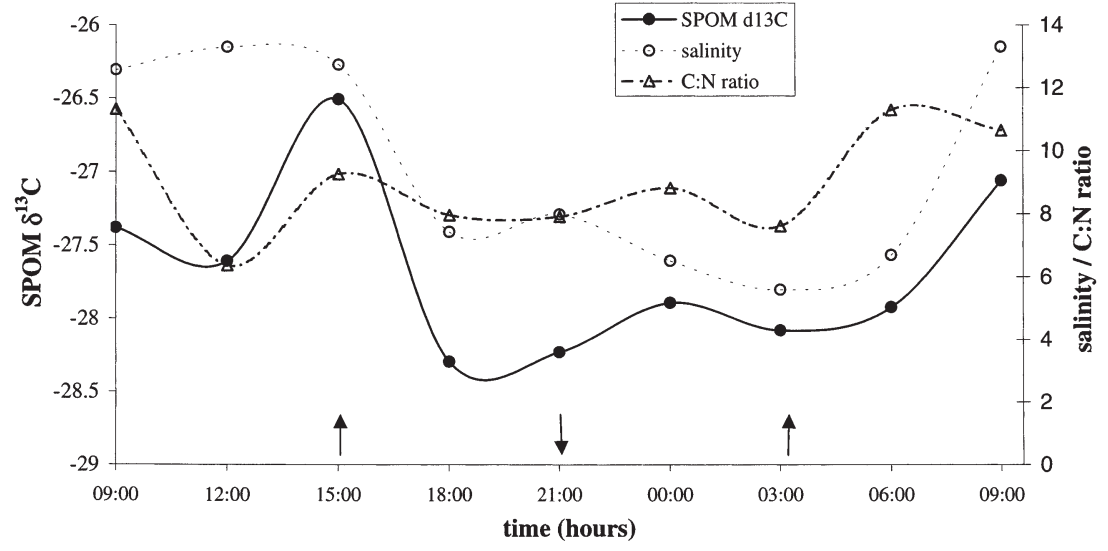

Fig. 5. Salinity (o), elemental composition $(\Delta)$ and stable carbon-isotope composition $(\bullet, \%)$ of suspended particulate organic matter collected during a $24 \mathrm{~h}$ period at the central Gaderu station $\left(\mathrm{G}_{3}\right)$ on 16/17 November 1995. Arrows pointing upwards: high tides; arrow pointing downwards: low tide
As observed for SPOM, most depleted values were usually observed between the middle of the monsoon period (i.e. September) and the middle of the dry season (i.e. February) (Fig. 7), and the range of $\delta^{15} \mathrm{~N}$ values observed at each station was larger than the average spatial differences (Table 3).

Zooplankton $\delta^{15} \mathrm{~N}$ values exhibited much less seasonal variation than the $\delta^{13} C_{\mathrm{ZP}}$ variations (Table 3 ). Due to the small sample sizes, it was impossible to analyse the $\delta^{15} \mathrm{~N}$ of all samples, which makes it difficult to detect any clear seasonal trend in zooplankton $\delta^{15} \mathrm{~N}$. Based on these data, however, it seems that Coringa zooplankton were lower in $\delta^{15} \mathrm{~N}(+4.76$ and $+5.22 \%$, $\mathrm{n}=$ 2) than that at the 3 other stations, which were relatively similar in their average $\delta^{15} \mathrm{~N}$ values (average $\delta^{15} \mathrm{~N}=+7.46 \%$ at $\mathrm{G}_{3 i}+7.92 \%$ at $\mathrm{K}_{2}$; and $+8.42 \%$ at $\mathrm{G}_{6}$ ). Due to the small amount of concurrent data from different stations, we were unable to detect any statistically significant spatial differences in $\delta^{15} \mathrm{~N}$.

\section{DISCUSSION}

\section{Sources of organic matter in SPOM}

Because of the high turbidity in the study area, aquatic macrophytes and seagrasses are virtually absent (Dehairs et al. 2000). The 3 main local primary producers to be considered are thus mangroves, phytoplankton, and benthic microalgae, of which the latter 2 are generally quantitatively much less important in turbid estuarine mangrove ecosystems (Roberston et al. 1992). In addition, some terrestrial detritus from outside the area, carried by the Gautami Godavari and
Fig. 6. Average zooplankton $\delta^{13} \mathrm{C}(\%)$ vs average SPOM $\delta^{13} \mathrm{C}$ (in \%) for different locations. Only concurrently collected samples were used to construct this figure. Error bars $= \pm 1 \mathrm{SD}$; dotted line represents $\delta^{13} \mathrm{C}$ for the zooplankton food source assuming fractionation of $1 \%$
Table 3. Average $( \pm 1 \mathrm{SD})$, minimum and maximum $\delta^{13} \mathrm{C}$ and $\delta^{15} \mathrm{~N}(\%)$ of zooplankton $(\mathrm{ZP})$, collected at different locations in the Gautami Godavari estuarine region. Some of the zooplankton $\delta^{13} \mathrm{C}$ data were taken from Dehairs et al. (2000). Abbreviations of sampling locations as in Fig. 1

\begin{tabular}{|ccccc|}
\hline & $\begin{array}{c}\text { Kakinada Bay } \\
\left(\mathrm{K}_{2}\right)\end{array}$ & $\begin{array}{c}\text { Coringa } \\
\left(\mathrm{C}_{1}\right)\end{array}$ & $\begin{array}{c}\text { Gaderu } \\
\left(\mathrm{G}_{3}\right)\end{array}$ & $\begin{array}{c}\text { Gautami Godavari } \\
\left(\mathrm{G}_{6}\right)\end{array}$ \\
\hline$\delta^{13} \mathrm{C}_{\mathrm{ZP}}$ & $-21.02 \pm 3.21(\mathrm{n}=19)$ & $-25.85 \pm 2.99(\mathrm{n}=9)$ & $-24.25 \pm 2.28(\mathrm{n}=14)$ & $-22.03 \pm 2.40(\mathrm{n}=13)$ \\
Min. & -28.19 & -30.13 & -26.92 & -27.63 \\
Max. & -16.45 & -20.62 & -19.10 & -18.85 \\
$\delta^{15} \mathrm{~N}_{\mathrm{ZP}}$ & $+7.92 \pm 1.42(\mathrm{n}=12)$ & $+4.99 \pm 0.33(\mathrm{n}=2)$ & $+7.46 \pm 0.86(\mathrm{n}=4)$ & $+8.42 \pm 1.17(\mathrm{n}=4)$ \\
Min. & +5.75 & +4.76 & +6.54 & +7.46 \\
Max. & +10.45 & +5.22 & +8.31 & +10.02 \\
\end{tabular}



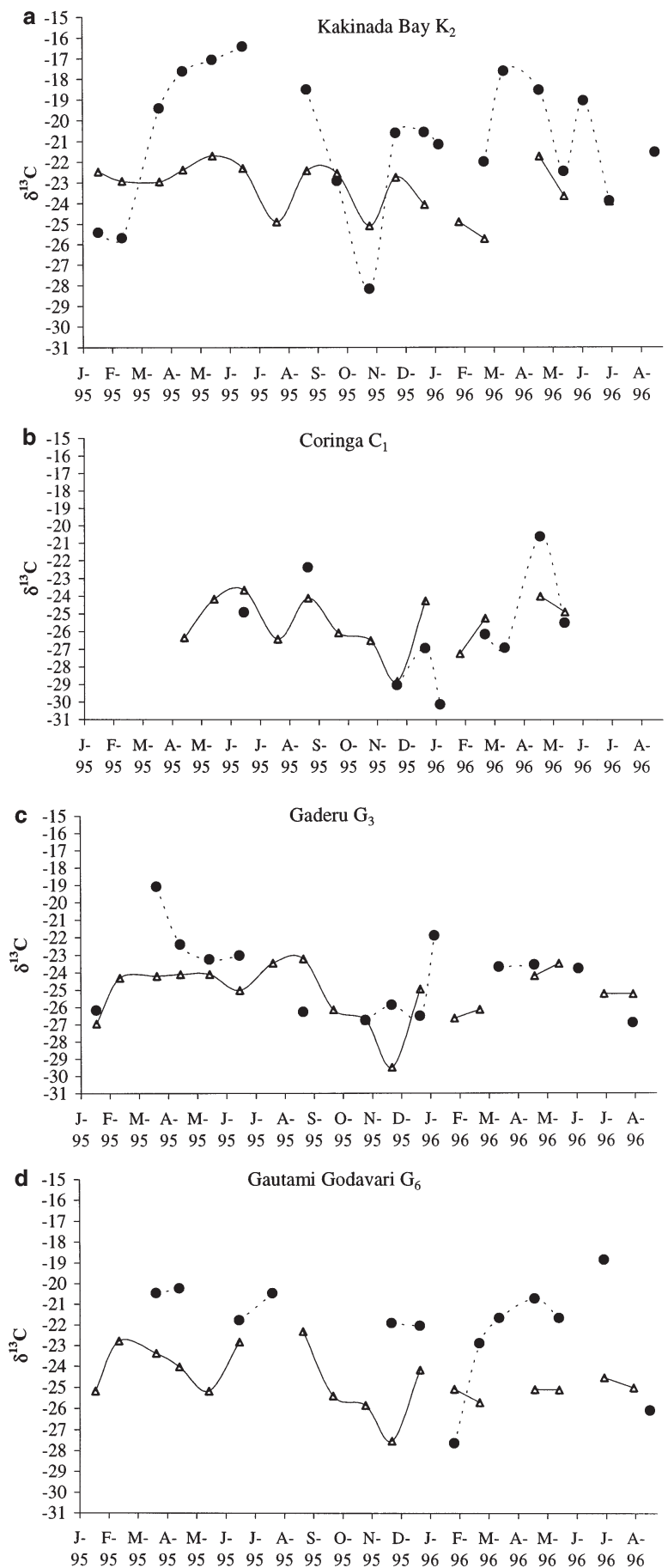

Fig. 7. Seasonal variation of zooplankton $\delta^{13} \mathrm{C}(\bullet)$ and SPOM $\delta^{13} \mathrm{C}(\Delta)$ at (a) Kakinada Bay $\mathrm{K}_{2,}$ (b) Coringa mouth $\mathrm{C}_{1}$, (c) central Gaderu $\mathrm{G}_{3}$, and (d) mouth of Gautami Godavari $\mathrm{G}_{6}$

entering Coringa and Gaderu, can be expected to contribute to the suspended organic matter load. Leaves of 7 out of 19 mangrove species occurring in the area showed an average $\delta^{13} \mathrm{C}$ signal of $-29.02 \pm 1.11 \%$
(Dehairs et al. 2000, S. Bouillon unpubl. data), which is consistent with literature data on these and other mangrove species (Rodelli et al. 1984, Zieman et al. 1984, Stoner \& Zimmerman 1988, Rezende et al. 1990, Hemminga et al. 1994, Rao et al. 1994, Cifuentes et al. 1996, Primavera 1996, Marguillier et al. 1997, France 1998), and which is a typical $\delta^{13} \mathrm{C}$-signature for terrestrial C3-plants. Factors reported to influence mangrove leaf $\delta^{13} \mathrm{C}$ include their water-use efficiency, salinity, and ambient humidity (Farquhar et al. 1982, Lin \& Sternberg 1992, Kao \& Chang 1998). Loneragan et al. (1997) found no seasonal differences in mangrove leaf $\delta^{13} \mathrm{C}$. Several authors have found no significant changes in the $\delta^{13} \mathrm{C}$ signal of mangrove leaves during decomposition (Zieman et al. 1984, Dehairs et al. 2000), so that we may assume that mangrove detritus exported into the water column also exhibits a carbonisotope signal in the same range as the measured $\delta^{13} \mathrm{C}$ values for mangrove leaves. Although fresh mangrove leaves are reported to have $\mathrm{C}: \mathrm{N}$ ratios ranging between 20 and 78 (average around 50), this ratio increases 2- to 3-fold during senescence due to reabsorption of 60 to $70 \%$ of the nitrogen by the plants (Rao et al. 1994, Jennerjahn \& Ittekot 1997). During subsequent decomposition and bacterial colonization, however, nitrogen enrichment occurs through nitrogen fixation (Woitchik et al. 1997) and immobilization, both on the forest floor (Twilley et al. 1992) and in the water column (Cifuentes et al. 1996). These processes result in much lower $\mathrm{C}: \mathrm{N}$ ratios for mangrove detritus. According to Cifuentes et al. (1996), suspended mangrove detritus (defined as suspended matter having a carbon-to-chlorophyll a ratio higher than 1000) has an average C:N ratio of 12.1, whereas other investigators report C:N ratios of 24 to 51 after $45 \mathrm{~d}$ of decomposition for Excoecaria agallocha and Avicennia marina, respectively (Dehairs et al. 2000), and C:N ratios approaching 24 after about $100 \mathrm{~d}$ decomposition for $A$. marina, A. corniculatum and Kandelia candel (Tam et al. 1990).

Because of the practical difficulties in obtaining phytoplankton samples free from terrestrial detritus, no $\delta^{13} \mathrm{C}$ data specifically for phytoplankton are available. It is generally accepted, however, that marine phytoplankton from tropical regions shows a $\delta^{13} \mathrm{C}$ signal between -18 and $-22 \%$ (Fontugne \& Duplessy 1981, Goericke \& Fry 1994), whereas estuarine and freshwater phytoplankton may be more depleted in ${ }^{13} \mathrm{C}$ due to the uptake of isotopically light DIC resulting from the bacterial respiration of terrestrial organic matter (Mook \& Tan 1991, Hellings et al. 1999). Phytoplankton $\mathrm{C}: \mathrm{N}$ ratios are reported to range typically from 6.6 to 8.7 (Redfield et al. 1963, Holligan et al. 1984).

Due to light limitation and inhibition by soluble tannins, benthic microalgal production in mangrove 
forests is usually very low (Alongi 1994 and references therein). In the following discussion, only phytoplankton and terrestrial (including mangrove) detritus will be considered as major components of SPOM.

In Kakinada Bay, suspended matter from Stns $K_{2}, K_{3}$, and $\mathrm{K}_{4}$ was significantly enriched in ${ }^{13} \mathrm{C}$ relative to all mangrove waterway stations (paired $t$-test), but values were generally more depleted than those reported for typical tropical marine phytoplankton. Several C:N ratios for suspended matter at these stations were relatively high (i.e. between 9 and 17.3) compared to typical phytoplankton $\mathrm{C}: \mathrm{N}$ ratios (6.6), which leads to the conclusion that a certain amount of terrestrial detritus is present at these locations. In view of the relative proximity to the mangrove waterways (e.g. about $4 \mathrm{~km}$ from $\mathrm{K}_{4}$ to the Coringa mouth: Fig. 1), it may be assumed that mangrove detritus constitutes at least a part of this terrestrial matter. suspended matter $\delta^{13} \mathrm{C}$ values at these stations also exhibited a fairly wide range $\left(-21.71\right.$ to $-25.75 \%$ o at $K_{2},-19.18$ to $-26.30 \%$ at $\mathrm{K}_{3}$, and -20.68 to $-26.43 \%$ at $\mathrm{K}_{4}$ ). This variability may have been caused simply by a variable contribution of terrestrial material to the local phytoplankton, but some samples which, judging from their low $\mathrm{C}: \mathrm{N}$ ratios $(<7)$ were dominated by phytoplankton, had $\delta^{13} \mathrm{C}$ values ranging between -21.57 and $-26.30 \%$, indicating that phytoplankton at these stations may also exhibit variations in its $\delta^{13} \mathrm{C}$ signal, e.g. due to the uptake of isotopically-light DIC (e.g. Hellings et al. 1999), variability in growth rate (e.g. Fry \& Wainright 1991, Burkhardt et al. 1999), or variability in ambient dissolved $\mathrm{CO}_{2}$ concentrations (Hinga et al. 1994, Burkhardt et al. 1999). suspended matter $\delta^{13} \mathrm{C}$ values from all Kakinada Bay stations showed only a minor seasonal pattern, although it is clear that all stations usually followed the same trend. Remarkably, the northernmost station $\left(\mathrm{K}_{1}\right)$, which is located in the opening of the bay into the Bay of Bengal, exhibited the most depleted average $\delta^{13} C_{\text {SPOM }}$ value, indicating a larger terrestrial influence than the central bay stations. It is unclear, however, whether this is the result of circulation patterns in the bay (Sreenivas 1998), which could direct the water flowing out of the mangrove waterways along a clockwise route to the bay opening $\left(\mathrm{K}_{1}\right)$, or because of a more direct influence by the Kakinada Canal (see Fig. 1), which opens into the western side of the bay on the south end of Kakinada town and carries substantial amounts of domestic waste. Satellite data show that the outflow of the Kakinada Canal is directed towards the bay opening, supporting the latter hypothesis. Either way, it seems that terrestrial detritus, presumably including mangrove-derived material, comprises a variable and detectable fraction of suspended matter in Kakinada Bay, several kilometres from the outlets of the mangrove creeks.
At all 3 Coringa stations, suspended matter had an average $\delta^{13} \mathrm{C}$ of $-25.5 \%$, which was the lowest average value encountered in this study. Of all the sites considered, Coringa is clearly least influenced by the saline bay water, so the $\delta^{13} \mathrm{C}_{\mathrm{SPOM}}$ values at these stations (especially at $\mathrm{C}_{3}$ which had an average salinity of 4.15 : Table 1) can be considered to be representative of the freshwater end-members of suspended matter $\delta^{13} \mathrm{C}$.

In Gaderu, suspended matter exhibited the lowest average $\delta^{13} \mathrm{C}$ at the central $\mathrm{G}_{3}$ station, and it became more enriched in ${ }^{13} \mathrm{C}$ towards both its marine ends (Table 1, Fig. 2). This gradient may be caused by a combination of 2 factors, i.e. a lesser admixture of marine phytoplankton with terrestrial material from the outer stations towards $\mathrm{G}_{3}$, or a depletion in ${ }^{13} \mathrm{C}$ in local phytoplankton in the central Gaderu station compared to the other stations. Contrary to the expectation that $\mathrm{C}: \mathrm{N}$ ratios would have been largest at $\mathrm{G}_{3}$ and lower towards the open water because of a possibly elevated contribution of mangrove detritus to suspended matter, the reverse pattern was observed (Table 1), suggesting that the observed trend in $\delta^{13} \mathrm{C}_{\mathrm{SPOM}}$ was not due solely to a larger contribution of terrestrial material. In addition, phytoplankton counts and chlorophyll measurements indicated that in Gaderu, phytoplankton was most abundant at $\mathrm{G}_{3}$ and diminished towards $\mathrm{G}_{1}$ and $\mathrm{G}_{5}$ (Rohini 1997). Thus, in Gaderu, a larger contribution of phytoplankton to suspended matter (at $\mathrm{G}_{3}$ ) was accompanied by more depleted $\delta^{13} \mathrm{C}_{\mathrm{SPOM}}$ values, suggesting that, on average, phytoplankton here may have been more ${ }^{13} \mathrm{C}$-depleted than the nearby bay phytoplankton.

If we consider $\delta^{13} \mathrm{C}_{\mathrm{SPOM}}$ data from all locations, it is clear that the stable carbon-isotope composition of suspended matter was very variable, and that seasonal variability was more pronounced than average spatial differences. Based on the wide range of $\mathrm{C}: \mathrm{N}$ ratios encountered (3.9 to 42.4), part of this variation may have been caused by a variable contribution of terrestrial and autochthonous material to the total suspended organic matter load. However, the wide range of $\delta^{13} \mathrm{C}$ values (e.g. $-21.57 \%$ at $\mathrm{K}_{4}$ to $-29.48 \%$ ot $\mathrm{G}_{3}$ ) in samples with low $\mathrm{C}: \mathrm{N}$ ratios $(\mathrm{C}: \mathrm{N}<7$, suggesting a substantial phytoplankton contribution) suggests that there was some spatial and temporal variation in phytoplankton $\delta^{13} \mathrm{C}$, which was supressed or masked in samples where the terrestrial contribution was high. Especially for the mangrove creeks, we expect local phytoplankton to have been relatively depleted in ${ }^{13} \mathrm{C}$, due to the uptake of isotopically light DIC, which results from the degradation of the large amounts of mangrove litter. In fact, a few preliminary $\delta^{13} \mathrm{C}_{\text {DIC }}$ results from Coringa surface-water samples collected in February 1999 showed significant ${ }^{13} \mathrm{C}$-depletion of the DIC pool, with $\delta^{13} \mathrm{C}$ values between $-10.5 \%$ at $\mathrm{C}_{3}$ and $-10.0 \%$ at $\mathrm{C}_{1}$. 
Furthermore, 2 relatively pure (visually assessed) phytoplankton samples $(10 \ll 50 \mu \mathrm{m})$ collected in Coringa at the same time as the samples assessed for $\delta^{13} \mathrm{C}_{\mathrm{DIC}}$ showed a $\delta^{13} \mathrm{C}$ of $-28.91 \%$ o (at $\left.\mathrm{C}_{3}\right)$ and $-26.87 \%$ o (at $\left.\mathrm{C}_{1}\right)$, respectively, i.e. they were depleted in ${ }^{13} \mathrm{C}$ relative to the average $\delta^{13} \mathrm{C}_{\mathrm{SPOM}}$ at these sites, and fell within the same range as $\delta^{13} \mathrm{C}$ values reported for mangrove leaves.

$\delta^{13} \mathrm{C}$ values of SPOM collected during a $24 \mathrm{~h}$ period at $\mathrm{G}_{3}$ in November 1995 showed substantial variations with the stage of the tide, with suspended matter being most depleted $(-28.30 \%)$ during low tide, and most enriched (-26.51\%o) at high tide (Fig. 5). Similar observations in tidal mangrove ecosystems were made by Rezende et al. (1990), and tidal variations in $\delta^{13} \mathrm{C}_{\mathrm{SPOM}}$ of an even greater magnitude (about $5 \%$ ) were observed by Cifuentes et al. (1996), even though the salinity fluctuations they encountered $(\Delta$ sal. $=1.7)$ were much smaller than those recorded in our study $(\Delta$ sal. $=7.5) . \delta^{13} \mathrm{C}_{\mathrm{SPOM}}$ values were well correlated with salinity $\left(\mathrm{R}^{2}=0.62 ; \mathrm{p}=0.012\right)$ but not with $\mathrm{C}: \mathrm{N}$ ratios $\left(R^{2}=0.14\right)$. These suspended matter $C: N$ ratios are within the same range as most other data reported from other mangrove ecosystems (e.g. Cifuentes et al. 1996).

\section{Zooplankton $\delta^{13} \mathrm{C}$ and its relation to $\operatorname{SPOM} \delta^{13} \mathrm{C}$}

Very little information exists on the trophic pathways associated with zooplankton in mangrove ecosystems, but Grindley (1984) suggested that the abundant particulate organic matter (i.e. detritus) in mangrove estuaries constitutes the major food source for zooplankton in these ecosystems, and similar conclusions have been made in temperate estuaries (e.g. Hummel et al. 1988). Camillieri \& Ribi (1986) showed experimentally that several species of small crustaceans are able to survive when offered flakes formed from DOC (dissolved organic carbon) leached from Rhizophora spp. leaves. The species they investigated included some harpacticoid copepods and amphipods (i.e. benthic organisms), but no calanoid copepods, which usually form the bulk of the pelagic zooplankton in the study area (Chandra Mohan et al. 1997). Moreover, the fact that these organisms are able to survive on this food source does not imply that they would utilise it under natural conditions, when more nutritious algal material is also present.

Careful comparison of the zooplankton and suspended matter $\delta^{13} \mathrm{C}$ data revealed several patterns which suggest that zooplankton were not feeding indiscriminately on bulk suspended matter, but selected components of the SPOM, presumably phytoplankton, that had a more pronounced spatial and seasonal variability in $\delta^{13} \mathrm{C}$ than SPOM.
Firstly, the overall range of $\delta^{13} \mathrm{C}$ values for zooplankton $\left(\delta^{13} \mathrm{C}_{\mathrm{ZP}}\right)$ collected at the 4 selected stations $(-30.13$ to $-16.45 \%$ ) was much larger than the range of $\delta^{13} \mathrm{C}_{\mathrm{SPOM}}$ values from those locations $(-29.48$ to $-21.71 \%$; Tables $1 \& 3$ ). If zooplankton were feeding indiscriminately on SPOM (and assuming a constant $\delta^{13} \mathrm{C}$ shift), the seasonal fluctuations of their $\delta^{13} \mathrm{C}$ values would have been of the same magnitude as those observed in SPOM. If, however, they were feeding selectively on either terrestrial detritus (which should have a fairly constant $\delta^{13} \mathrm{C}$ ) or phytoplankton (which may have a more variable $\delta^{13} \mathrm{C}$ ), the fluctuations of their $\delta^{13} \mathrm{C}$ signal should have been either smaller or larger than those of SPOM, respectively.

Secondly, the average zooplankton $\delta^{13} \mathrm{C}$ of the 4 sampling locations followed the same trend in ${ }^{13} \mathrm{C}$-depletion as did the suspended matter from these stations (i.e. $\mathrm{K}_{2}>\mathrm{G}_{6}>\mathrm{G}_{3}>\mathrm{C}_{1}$ ), but the $\delta^{13} \mathrm{C}$ gradient was more pronounced in the zooplankton (Fig. 6), causing zooplankton to be on average enriched in ${ }^{13} \mathrm{C}$ relative to the suspended matter at $\mathrm{K}_{2}$ (by $1.80 \%$ when using only data from months when both parameters were measured), at $\mathrm{G}_{6}$ (by $2.92 \%$ ) and at $\mathrm{G}_{3}$ (by $0.07 \%$ ), but depleted at $\mathrm{C}_{1}$ (by $0.10 \%$ ). If we assume a constant and small fractionation in ${ }^{13} \mathrm{C}$ between zooplankton and their diet $(1 \%$; DeNiro \& Epstein 1978), this would suggest that at $K_{2}$ and $G_{6}$, zooplankton were feeding on a fraction enriched in ${ }^{13} \mathrm{C}$ relative to the total suspended matter, but on a fraction that was ${ }^{13} \mathrm{C}$-depleted relative to SPOM at $\mathrm{G}_{3}$ and $\mathrm{C}_{1}$. Del Giorgio \& France (1996) found from a compilation of literature data that there is a trend in the mean difference between $\delta^{13} \mathrm{C}_{\mathrm{ZP}}$ and $\delta^{13} \mathrm{C}_{\mathrm{SPOM}}$ going from the open ocean $(+2.7 \%)$, coastal $(+1.8 \%)$ and estuarine $(+0.8 \%)$ ecosystems, to freshwater lakes, where zooplankton is depleted relative to SPOM by an average of $2.7 \%$. The most likely explanation for this trend is that zooplankton feeds selectively on phytoplankton which, in freshwater and sometimes in estuarine systems, is isotopically lighter than the total suspended matter (del Giorgio \& France 1996).

A third argument for selectivity in zooplankton feeding comes from a comparison of the average difference in $\delta^{13} \mathrm{C}_{\mathrm{SPOM}}$ and the average difference in $\delta^{13} \mathrm{C}_{\mathrm{ZP}}$ between different stations, as shown in Fig. 8. Although the spatial differences in $\delta^{13} \mathrm{C}_{\mathrm{SPOM}}$ are often significant (paired $t$-test), they are relatively small (0.3 to $2.1 \%$ ) compared to the difference in the zooplankton $\delta^{13} \mathrm{C}$ signal between these locations ( 1.4 to $6.0 \%$ ). If zooplankton would have been feeding indiscriminately on SPOM, these between-site differences would be expected to be of equal magnitude for both SPOM and zooplankton.

Although these data do not allow us to quantitatively determine the exact contribution of phytoplankton or terrestrial carbon to zooplankton nutrition, our results 


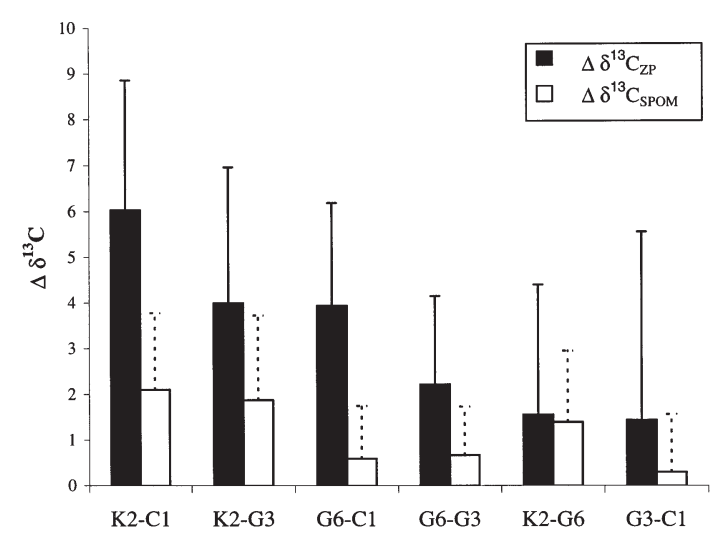

Fig. 8. Average difference in zooplankton $\delta^{13} \mathrm{C}$ (black bars) and average difference in SPOM $\delta^{13} \mathrm{C}$ (white bars) for different pairs of locations. Error bars $=+1 \mathrm{SD}$

clearly indicate that phytoplankton constitutes a more important carbon source for zooplankton, despite the high inputs of terrestrial (mangrove) carbon in the aquatic system.

\section{Possible mechanisms influencing spatio-temporal variations in SPOM and zooplankton $\delta^{13} \mathrm{C}$}

The selective feeding of zooplankton on phytoplankton (discussed above) implies that the $\delta^{13} C_{\mathrm{ZP}}$ will provide us with a better parameter than $\delta^{13} \mathrm{C}_{\mathrm{SPOM}}$ for elucidating possible mechanisms influencing the stable carbon-isotope signal of the phytoplankton in the study area. Some important factors influencing the $\delta^{13} \mathrm{C}$ of phytoplankton have been found to include the $\delta^{13} \mathrm{C}$ of the DIC pool and the phytoplankton growth rate (e.g. Fry \& Wainright 1991, Hellings et al. 1999). To our knowledge, no studies have previously attempted to analyse the seasonal variability of phytoplankton $\delta^{13} \mathrm{C}$ in tropical, monsoon-influenced estuaries.

As for the spatial variability, there is a clear trend towards higher $\delta^{13} \mathrm{C}$ values for zooplankton (and, to a lesser degree for SPOM) with increasing salinity, i.e. from more depleted $\delta^{13} \mathrm{C}$ values in the most freshwater parts (Coringa), and a gradual increase towards more estuarine $\left(\mathrm{G}_{3}, \mathrm{G}_{6}\right)$ and near-marine $\left(\mathrm{K}_{2}\right)$ locations. As to the magnitude of this longitudinal $\delta^{13} \mathrm{C}$ gradient, it should be noted that, in view of the relatively small area considered, there was a remarkably high average difference in $\delta^{13} \mathrm{C}_{\mathrm{ZP}}$ between the mouth of Coringa $\left(\mathrm{C}_{1}\right)$ and central Kakinada Bay $\left(\mathrm{K}_{2}\right)$ of about $6 \%$ (Table 3, Fig. 8). The phytoplankton $\delta^{13} \mathrm{C}$ difference between these stations might have been even larger, as we have no indication concerning the precise degree of selectivity in zooplankton feeding. This longitudinal gradi- ent may be determined principally by an accompanying gradient in $\delta^{13} \mathrm{C}_{\mathrm{DIC}}$, which might have been more negative in the mangrove sites due to the microbial respiration of the higher amounts of terrestrial POC available; but apart from an indication by the few $\delta^{13} \mathrm{C}_{\text {DIC }}$ measurements made in Coringa (see above), we have no conclusive evidence for this so far. Bearing in mind possible effects of tidal amplitude and year-toyear variations in the climatic pattern on the stable carbon-isotope composition of SPOM, the following trends seem to be a general feature in the $\delta^{13} C_{Z P}$ signal (Fig. 7): (1) During the pre-monsoon period (i.e. March-April to May-June), when salinity is high in the entire area and the suspended organic matter load is minimal (Dehairs et al. 2000), zooplankton is enriched in ${ }^{13} \mathrm{C}$ relative to its average $\delta^{13} \mathrm{C}$ signal. The small amount of data from the first half of the monsoon period (July to August) seem to suggest that the $\delta^{13} C_{Z P}$ remains high during this period (Fig. 7). (2) Minimal values of $\delta^{13} \mathrm{C}_{\mathrm{ZP}}$ are observed between the middle of the monsoon period and the middle of the dry season (i.e. between September and February).

The pre-monsoon period, during which most ${ }^{13} \mathrm{C}$ enriched zooplankton were observed (especially in Kakinada Bay) coincided with a period of increased phytoplankton abundance, presumably induced by the lower turbidity during this period (Rohini 1997). ${ }^{13} \mathrm{C}$ enrichment in SPOM or phytoplankton during periods of higher phytoplankton biomass or higher chlorophyll concentrations has been observed in several studies (e.g. Fry \& Wainright 1991, Ogawa \& Ogura 1997, Burkhardt et al. 1999), although there remains some discussion on the precise mechanisms causing this enrichment. It remains to be determined to what effect the high $\delta^{13} \mathrm{C}_{\mathrm{ZP}}$ values encountered during pre-monsoon period are a reflection of increased phytoplankton growth rate, or a less negative $\delta^{13} C_{\text {DIC }}$ caused by the lesser dilution of the DIC pool by ${ }^{13} \mathrm{C}$-depleted respired $\mathrm{CO}_{2}$.

Minimum $\delta^{13} \mathrm{C}$ values were encountered between the second half of the monsoon period and the first half of the dry period (i.e. between September and February). We had expected lowest $\delta^{13} \mathrm{C}$ values to occur during the monsoon period (July to September), when the large amounts of terrestrial detritus released (Gupta et al. 1997) might have lowered the $\delta^{13} C_{\text {DIC }}$ signal because of increased microbial activity. Our data seem to suggest that the ${ }^{13} \mathrm{C}$-depletion of the DIC pool does not occur until some time after the initiation of the monsoon, and that this depletion may persist for several months after the freshwater inflow has almost ceased. The few measurements of $\delta^{13} \mathrm{C}_{\text {DIC }}$ and $\delta^{13} \mathrm{C}$ of size-fractionated phytoplankton made in Coringa, which indicated significant ${ }^{13} \mathrm{C}$-depletion, were carried out in February, thus providing further evidence that this 
period still experiences low $\delta^{13} \mathrm{C}$ values. More recent data on zooplankton isotope composition from this area also confirm this general pattern (S. Bouillon unpubl. data). Correlating our carbon-isotope data with salinity, POC load (Dehairs \& Rao 1997), or oxygen concentrations (Sreenivas 1998) has not provided any clear relationships that might explain this depletion. One explanation might be that there is a certain time lag between the occurrence of high POC loads (i.e. when the monsoon period starts) and the build-up of a ${ }^{13} \mathrm{C}$-depleted DIC pool due to the microbial degradation of this material. After the freshwater inflow has again reached minimal values, further degradation of the deposited terrestrial material may explain the persistence of the low $\delta^{13} \mathrm{C}$ values encountered. A closer monitoring of $\delta^{13} \mathrm{C}_{\mathrm{SPOM}}, \delta^{13} \mathrm{C}_{\mathrm{ZP}}$, and especially $\delta^{13} \mathrm{C}_{\mathrm{DIC}}$ and phytoplankton growth rate should provide clearer insights into this.

\section{Zooplankton $\delta^{15} \mathrm{~N}$ variability}

Zooplankton $\delta^{15} \mathrm{~N}$ values exhibited much less seasonal variation compared to the $\delta^{13} \mathrm{C}_{\mathrm{ZP}}$ variations (Table 3). Due to the small amount of $\delta^{15} \mathrm{~N}$ data, it is difficult to detect any clear seasonal trend in zooplankton $\delta^{15} \mathrm{~N}$. Based on these few data however, it seems that Coringa zooplankton had lower $\delta^{15} \mathrm{~N}$ values $(+4.76$ and $+5.22 \%, \mathrm{n}=2$ ) than did zooplankton at the 3 other stations, which showed relatively similar average $\delta^{15} \mathrm{~N}$ values (average $\delta^{15} \mathrm{~N}=+7.46 \%$ at $\mathrm{G}_{3 i}+7.92 \%$ at $\mathrm{K}_{2}$; and $+8.42 \%$ at $\mathrm{G}_{6}$ ). Because of the small amount of concurrent data from different stations, we were unable to detect any statistically significant spatial differences in $\delta^{15} \mathrm{~N}$, but it does appear that the estuarine and near-marine stations $\left(\mathrm{G}_{6}\right.$ and $\left.\mathrm{K}_{2}\right)$ were more enriched in ${ }^{15} \mathrm{~N}$ than Gaderu and, especially, Coringa. It is well known that marine invertebrates, including zooplankton, are usually more ${ }^{15} \mathrm{~N}$-enriched than freshwater invertebrates (e.g. France 1994), and this has been ascribed to the ${ }^{15} \mathrm{~N}$-enriched inorganic $\mathrm{N}$-pool that occurs under lower $\mathrm{N}$-concentrations through the selective uptake of ${ }^{14} \mathrm{~N}$ by phytoplankton (e.g. Altabet \& Francois 1994). In this study area, average nitrate concentrations in the northern Kakinada Bay (4.9 to $6.5 \mathrm{mmol} \mathrm{l}^{-1}$ : Murthy 1997) were indeed lower than those found in Gaderu (6.6 to $15.0 \mu \mathrm{mol} \mathrm{l}^{-1}$ ) or Coringa (12.6 ot $16.4 \mathrm{~mol} \mathrm{l}^{-1}$ ). The Gautami Godavari station $\left(\mathrm{G}_{6}\right)$, however, had both a high average nitrate concentration $\left(15.3 \mu \mathrm{mol} \mathrm{l}^{-1}\right)$ and a high $\delta^{15} \mathrm{~N}(+8.42 \%)$. On the other hand, anthropogenic inputs of $\mathrm{N}$ (via wastewater) can significantly increase the $\delta^{15} \mathrm{~N}$ in aquatic ecosystems (e.g. McClelland \& Valiela 1998 and references therein), and in our case large amounts of domestic wastewater enter the Kakinada Bay via the
Kakinada Canal (Fig. 1). Preliminary results from benthic invertebrates and fishes also show a clear enrichment in ${ }^{15} \mathrm{~N}$ between the mangrove areas and Kakinada Bay of about $2 \%$ (S. Bouillon unpubl. data), but further studies are needed to determine the factors responsible for this enrichment in ${ }^{15} \mathrm{~N}$.

Acknowledgements. Financial support was granted by the EC projects 'Assessment of the ecological importance of mangroves in the Kakinada Area, Andhra Pradesh, India (contract CI1 ${ }^{*}$ CT930320)' and 'Assessment of mangrove degradation and resilience in the Indian sub-continent (contract ERB IC18CT98-0295)'. F. Dehairs is a Senior Research Associate at the Fund for Scientific Research Flanders (FWO-Vlaanderen). We are grateful to E. Keppens and K. van den Driessche for granting us access to the mass spectrometer and for their assistance during the measurement operations. We would also like to thank 4 anonymous reviewers for their useful comments, which greatly improved an earlier draft of this manuscript.

\section{LITERATURE CITED}

Alongi DM (1994) Zonation and seasonality of benthic primary production and community respiration in tropical mangrove forests. Oecologia 98:320-327

Altabet MA, Francois R (1994) Sedimentary nitrogen isotopic ratio as a recorder for surface ocean nitrate utilization. Global Biogeochem Cycles 8:103-116

Ambler JW, Alcala-Herrera J, Burke R (1994) Trophic roles of particle feeders and detritus in a mangrove island prop root ecosystem. Hydrobiologia 292/293:437-446

Azariah J, Azariah H, Gunasekaran S, Selvam V (1992) Structure and species distribution in Coringa mangrove forest, Godavari Delta, Andhra Pradesh, India. Hydrobiologia 247:11-16

Bunn SE, Loneragan NR, Kempster MA (1995) Effects of acid washing on stable isotope ratios of $\mathrm{C}$ and $\mathrm{N}$ in penaeid shrimps and seagrass: implications for food web studies using stable isotopes. Limnol Oceanogr 40:622-625

Burkhardt S, Riebesell U, Zondervan I (1999) Stable carbon isotope fractionation by marine phytoplankton in response to daylength, growth rate, and $\mathrm{CO}_{2}$ availability. Mar Ecol Prog Ser 184:31-41

Camilleri JC, Ribi G (1986) Leaching of dissolved organic carbon (DOC) from dead leaves, formation of flakes from DOC, and feeding on flakes by crustaceans in mangroves. Mar Biol 91:337-344

Chandra Mohan P, Sreenivas N, Prasad NV, Rao AVVS (1997) Zooplankton diversity and seasonal fluctuations in Kakinada Bay with special reference to mangrove habitat. In: Dehairs F (ed) An assessment of the ecological importance of mangroves in the Kakinada area, Andhra Pradesh, India. (Final report of European Community INCO-DC contract CI1 ${ }^{*}$ CT930320, Part II). Vrije Universiteit, Brussels, p 1-21

Cifuentes LA, Coffin RB, Solorzano L, Cardenas W, Espinoza J, Twilley RR (1996) Isotopic and elemental variations of carbon and nitrogen in a mangrove estuary. Estuar Coast Shelf Sci 43:781-800

Clough BF (1992) Primary productivity and growth of mangrove forests. In: Robertson AI, Alongi DM (eds) Tropical mangrove ecosystems. American Geophysical Union, Washington, DC, p 225-249

Coplen TB (1996) New guidelines for reporting stable hydro- 
gen, carbon and oxygen isotopic ratios. Geochim Cosmochim Acta 60:3359-3360

Deegan LA, Garrit RH (1997) Evidence for spatial variability in estuarine food webs. Mar Ecol Prog Ser 147:31-37

Dehairs F, Rao RG (1997) Tracing carbon flow in the mangrove ecosystem of Godavari Delta, India. In: Dehairs F (ed) An assessment of the ecological importance of mangroves in the Kakinada area, Andhra Pradesh, India. (Final report of European Community INCO-DC contract CI1 * CT930320, Part II) Vrije Universiteit, Brussels, p 1-21

Dehairs F, Rao RG, Chandra Mohan P, Raman V, Marguillier S, Hellings L (2000) Tracing mangrove carbon in suspended matter and aquatic fauna of the Gautami-Godavari Delta, Bay of Bengal (India). Hydrobiologia 431:225-241

del Giorgio PA, France RL (1996) Ecosystem-specific patterns in the relationship between zooplankton and POM or microplankton $\delta^{13} \mathrm{C}$. Limnol Oceanogr 41:359-365

DeMott WR (1988) Discrimination between algae and detritus by freshwater and marine zooplankton. Bull Mar Sci 43:486-499

DeMott WR (1995) Food selection by calanoid copepods in response to between-lake variation in food abundance. Freshw Biol 33:171-180

DeNiro MJ, Epstein S (1978) Influence of diet on the distribution of carbon isotopes in animals. Geochim Cosmochim Acta 42:495-506

Dittel AI, Epifiano CE, Cifuentes LA, Kirchman DL (1997) Carbon and nitrogen sources for shrimp postlarvae fed natural diets from a tropical mangrove system. Estuar Coast Shelf Sci 45:629-637

Faganeli J, Malej A, Pezdic J, Malacic V (1988) C-N-P ratios and stable $\mathrm{C}$ isotopic ratios as indicators of sources of organic matter in the Gulf of Trieste (Northern Adriatic). Oceanol Acta 11:377-382

Fantle MS, Dittel AI, Schwalm SM, Epifiano CE, Fogel ML (1999) A food web analysis of the juvenile blue crab, Callinectes sapidus, using stable isotopes in whole animals and individual amino acids. Oecologia 120:416-426

Farquhar GD, Ball MC, van Caemmerer S, Roksandic Z (1982) Effect of salinity and humidity on $\delta^{13} \mathrm{C}$ value of halophytes-evidence for diffusional isotope fractionation determined by the ratio of intercellular/atmospheric partial pressure of $\mathrm{CO}_{2}$ under different environmental conditions. Oecologia 52:121-124

Fleming M, Lin G, Sternberg L da SL (1990) Influence of mangrove detritus in an estuarine ecosystem. Bull Mar Sci 47:663-669

Fontuyne MR, Duplessy JC (1981) Organic carbon isotopic fractionation by marine plankton in the temperature range -1 to -31 degrees. Oceanol Acta 4:85-90

France RL (1994) Nitrogen isotopic composition of marine and freshwater invertebrates. Mar Ecol Prog Ser 115:205-207

France R (1998) Estimating the assimilation of mangrove detritus by fiddler crabs in Laguna Joyuda, Puerto Rico, using dual stable isotopes. J Trop Ecol 14:413-425

Fry B, Wainright SC (1991) Diatom sources of ${ }^{13} \mathrm{C}$-rich carbon in marine food webs. Mar Ecol Prog Ser 76:149-157

Gattuso JP, Frankignoulle M, Wollast R (1998) Carbon and carbonate metabolism in coastal aquatic ecosystems. Annu Rev Ecol Syst 29:405-434

Goericke R, Fry B (1994) Variations of marine plankton $\delta^{13} \mathrm{C}$ with latitude, temperature, and dissolved $\mathrm{CO}_{2}$ in the world ocean. Global Biogeochem Cycles 8:85-90

Goering J, Alexander V, Haubenstock N (1990) Seasonal variability of stable carbon and nitrogen isotope ratios of organisms in a north Pacific bay. Estuar Coast Shelf Sci 30:239-260
Grindley JR (1984) The zooplankton of mangrove estuaries In: Por FD, Dor I (eds) Hydrobiology of the mangal. The ecosystem of the mangrove forests. (Devs Hydrobiol No. 20) Dr. W. Junk Publishers, The Hague, p 79-87

Gupta LP, Subramanian V, Ittekot V (1997) Biogeochemistry of particulate organic matter transported by the Godavari River, India. Biogeochemistry 38:103-128

Hellings L, Dehairs F, Tackx M, Keppens E, Baeyens W (1999) Origin and fate of organic carbon in the freshwater part of the Scheldt Estuary as traced by stable carbon isotopic composition. Biogeochemistry 47:167-186

Hemminga MA, Slim FJ, Kazungu J, Ganssen GM, Nieuwenhuize J, Kruyt NM (1994) Carbon outwelling from a mangrove forest with adjacent seagrass beds and coral reefs (Gazi Bay, Kenya). Mar Ecol Prog Ser 106:291-301

Hinga KR, Arthur MA, Pilson MEQ, Whitaker D (1994) Carbon isotope fractionation by marine phytoplankton in culture: the effects of $\mathrm{CO}_{2}$ concentration, $\mathrm{pH}$, temperature, and species. Global Biogeochem Cycles 8:91-102

Holligan PM, Harris RP, Newell RC, Harbour DS, Head RN, Linley EAS, Lucas MI, Tranter PRG, Weekley CM (1984) Vertical distribution and partitioning of organic carbon in mixed, frontal and stratified waters of the English Channel. Mar Ecol Prog Ser 14:111-127

Hummel H, Moerland G, Bakker C (1988) The concomitant existence of a typical coastal and a detritus food chain in the Westerschelde estuary. Hydrobiol Bull 22:35-41

Jennerjahn TC, Ittekot V (1997) Organic matter in sediments in the mangrove areas and adjacent continental margins of Brazil. I. Amino acids and hexosamines. Oceanol Acta 20:359-370

Kao WY, Chang KW (1998) Stable carbon isotope ratio and nutrient content of the Kandelia candel mangrove populations of different growth forms. Bot Bull Acad Sin Taipei 39:39-45

Kristensen E, Andersen FO, Kofoed LH (1988) Preliminary assessment of benthic community metabolism in a southeast Asian mangrove swamp. Mar Ecol Prog Ser 48: $137-145$

Lee SY (1995) Mangrove outwelling: a review. Hydrobiologia 295:203-212

Lin G, Sternberg L da SL (1992) Differences in morphology, carbon isotope ratios, and photosynthesis between scrub and fringe mangroves in Florida, USA. Aquat Bot 42:303-313

Loneragan NR, Bunn SE, Kellaway DM (1997) Are mangroves and seagrasses sources of organic carbon for penaeid prawns in a tropical Australian estuary? A multiple stableisotope study. Mar Biol 130:289-300

Malej A, Faganeli J, Pezdic J (1993) Stable isotope and biochemical fractionation in the marine pelagic food chain: the jellyfish Pelagia noctiluca and net zooplankton. Mar Biol 116:565-570

Marguillier S, van der Velde G, Dehairs F, Hemminga MA, Rajagopal S (1997) Trophic relationships in an interlinked mangrove-seagrass ecosystem as traced by $\delta^{13} \mathrm{C}$ and $\delta^{15} \mathrm{~N}$. Mar Ecol Prog Ser 151:115-121

McClelland JW, Valiela I (1998) Linking nitrogen in estuarine producers to land-derived sources. Limnol Oceanogr 43:577-585

Middelburg JJ, Nieuwenhuize J (1998) Carbon and nitrogen isotopes in suspended matter and sediments from the Schelde Estuary. Mar Chem 60:217-225

Minagawa W, Wada E (1984) Stepwise enrichment of ${ }^{15} \mathrm{~N}$ along food chains: further evidence and the relation between $\delta^{15} \mathrm{~N}$ and animal age. Geochim Cosmochim Acta 48:1135-1140

Mook WG, Tan FC (1991) Stable carbon isotopes in rivers and estuaries. In: Degens ET, Kempe S, Richey JE (eds) Bio- 
geochemistry of major world rivers. Scope, John Wiley \& Sons Ltd, London, p 245-264

Murthy NVSS (1997) Hydrography. In: Dehairs F (ed) An assessment of the ecological importance of mangroves in the Kakinada area, Andhra Pradesh, India. (Final report of European Community INCO-DC contract CI1 * CT930320, Part III). Vrije Universiteit, Brussels, p 16-25

Newell RIE, Marshall N, Sasekumar A, Chong VC (1995) Relative importance of benthic microalgae, phytoplankton, and mangroves as sources of nutrition for penaeid prawns and other coastal invertebrates from Malaysia. Mar Biol 123:595-606

Odum WE, Heald EJ (1972) Trophic analysis of an estuarine mangrove community. Bull Mar Sci 22:671-737

Ogawa N, Ogura N (1997) Dynamics of particulate organic matter in the Tamagawa estuary and inner Tokyo bay. Estuar Coast Shelf Sci 44:263-273

Owens NJP (1987) Natural variations in ${ }^{15} \mathrm{~N}$ in the marine environment. Adv Mar Biol 24:389-451

Peterson BJ, Fry B (1987) Stable isotopes in ecosystem studies. Annu Rev Ecol Syst 18:293-320

Primavera JH (1996) Stable carbon isotope ratios of penaeid juveniles and primary producers in a riverine mangrove in Guimeras, Phillipines. Bull Mar Sci 58:675-683

Rao RG, Woitchik AF, Goeyens L, van Riet A, Kazungu J, Dehairs F (1994) Carbon, nitrogen contents and stable isotope abundance in mangrove leaves from an east African coastal lagoon (Kenya). Aquat Bot 47:175-162

Redfield AC, Ketchum BH, Richards FA (1963) The influence of organisms on the composition of seawater. In: Hill MN (ed) The sea, Vol 2. Wiley, New York, p 26-77

Rezende CE, Lacerda LD, Ovalle ARC, Silva CAR, Martinelli LA (1990) Nature of POC transport in a mangrove ecosystem: a carbon stable isotopic study. Estuar Coast Shelf Sci 30:641-645

Robertson AI, Alongi DM, Boto KG (1992) Food chains and carbon fluxes. In: Robertson AI, Alongi DM (eds) Tropical mangrove ecosystems. American Geophysical Union, Washington, DC, p 293-326

Rodelli MR, Gearing JN, Gearing PJ, Marshall N, Sasekumar A (1984) Stable isotope ratios as a tracer of mangrove carbon in Malaysian ecosystems. Oecologia 61:326-333

Rohini T (1997) Phytoplankton. In: Dehairs F (ed) An assessment of the ecological importance of mangroves in the Kakinada area, Andhra Pradesh, India. (Final report of European Community INCO-DC contract CI1 * CT930320, Part III). Vrije Universiteit, Brussels, p 26-32

Satyanarayana B (1997) Biology of mangroves. In: Dehairs

Editorial responsibility: Otto Kinne (Editor), Oldendorf/Luhe, Germany
F (ed) An assessment of the ecological importance of mangroves in the Kakinada area, Andhra Pradesh, India. (Final report of European Community INCO-DC contract CI1*CT930320, Part III). Vrije Universiteit, Brussels, p 13-15

Sreenivas NV (1998) Zooplankton composition and distribution in mangrove habitat of Godavari Estuary - Kakinada. PhD thesis, Andhra University, Andhra Pradesh

Stoner AW, Zimmerman RJ (1988) Food pathways associated with penaeid shrimps in a mangrove-fringed estuary. Fish Bull 86:543-551

Sullivan MJ, Moncreiff CA (1990) Edaphic algae are an important component of salt marsh food webs: evidence from multiple stable isotope analysis. Mar Ecol Prog Ser 62:149-159

Tam NFY, Vrijmoed LLP, Wong YS (1990) Nutrient dynamics associated with leaf decomposition in a small subtropical mangrove community in Hong Kong. Bull Mar Sci 47:67-78

Toda H, Wada E (1990) Use of ${ }^{15} \mathrm{~N} /{ }^{14} \mathrm{~N}$ ratios to evaluate the food source of the mysid, Neomysis intermedia Czerniawsky, in a eutrophic lake in Japan. Hydrobiologia 194: 85-90

Turner JT, Tester PA (1989) Zooplankton feeding ecology: nonselective grazing by the copepods Acartia tonsa Dana, Centropages velificatus De Oliveira, and Eucalanus pileatus Giesbrecht in the plume of the Mississippi River. J Exp Mar Biol Ecol 126:21-43

Twilley RR, Chen RH, Hargis T (1992) Carbon sinks in mangrove forests and their implications to the carbon budget of tropical coastal ecosystems. Wat Air Soil Pollut 64:265-288

Wainright SC, Fry B (1994) Seasonal variation of the stable isotopic compositions of coastal marine plankton from Woods Hole, Massachusetts and Georges Bank. Estuaries 17:552-560

Woitchik AF, Ohowa B, Kazungu JM, Rao RG, Goeyens L, Dehairs F (1997) Nitrogen enrichment during decomposition of mangrove litter in an east African coastal lagoon (Kenya): relative importance of biological nitrogen fixation. Biogeochemistry 39:15-35

Yoshioka T, Wada E, Hayashi H (1994) A stable isotope study on seasonal food web dyamics in a eutrophic lake. Ecology 75:835-846

Zieman JC, Macko SA, Mills L (1984) Role of seagrasses and mangroves in estuarine food webs: temporal and spatial changes in stable isotope composition and amino acid content during decomposition. Bull Mar Sci 35:380-392

Zohary T, Erez J, Gophen M, Berman-Frank I, Stiller M (1994) Seasonality of stable carbon isotopes within the pelagic food web of Lake Kinneret. Limnol Oceanogr 39:1030-1043

Submitted: November 19, 1999; Accepted: May 11, 2000 Proofs received from author(s): November 13, 2000 